\title{
PENINGKATAN PENGETAHUAN IBU RUMAH TANGGA TENTANG PERILAKU HIDUP BERSIH DAN SEHAT TATANAN RUMAH TANGGA DALAM UPAYA PENCEGAHAN CORONA VIRUS DISEASE 2019 \\ INCREASING KNOWLEDGE OF HOUSEWIVES ABOUT HEALTHY BEHAVIOR AND IMPLEMENTING CLEAN AND HEALTHY BEHAVIOR HOUSEWIVES REGARDING EFFORTS TO PREVENT CORONA VIRUS DISEASE 2019
}

\author{
Jeini Ester Nelwan'), Oksfriani Jufri Sumampouw ${ }^{2)}$, Ester Candrawati Musa ${ }^{3)}$ \\ ${ }^{1}$ Department of Epidemiology and Biostatistics of the Faculty of Public Health, Sam Ratulangi University, Manado \\ ${ }^{2}$ Department of Environmental Health, Faculty of Public Health, Sam Ratulangi University, Manado \\ ${ }^{3}$ Department of Nutrition, Faculty of Public Health, Sam Ratulangi University, Manado \\ Email: jeini_ester83@unsrat.ac.id
}

\begin{abstract}
Abstrak: Corona virus disease 2019 (Covid 19) sedang melanda dunia termasuk Indonesia dan kota Manado. Oleh karena itu diperlukan upaya promosi kesehatan tentang upaya pencegahan Covid-19 seperti pelaksanaan PHBS tatanan rumah tangga. Kegiatan ini dilakukan melalui ceramah dan menggunakan media leaflet pada ibu rumah tangga yang tergabung pada PKK Dasawisma 2 Lingkungan 6 Kelurahan Taas Kecamatan Tikala Kota Manado sebanyak 30 orang. Variabel yang diukur yaitu tingkat pengetahuan menggunakan kuesioner. Hasil kegiatan menunjukkan bahwa berdasarkan pengukuran tingkat pengetahuan tentang PHBS tatanan rumah tangga semuanya masuk pada kategori baik. Namun ada beberapa indikator yang masih perlu ditingkatkan seperti mencuci tangan dengan benar dan beraktifitas fisik setiap hari minimal 30 menit.
\end{abstract}

Kata kunci: pengetahuan; ibu rumah tangga; PHBS

\begin{abstract}
Abtract: Corona virus disease (Covid 19) is currently sweeping the world, including Indonesia and the city of Manado. Therefore, health promotion efforts are needed regarding efforts to prevent Covid-19, such as implementing clean and healthy behavior in household. This activity was carried out through lectures and using leaflet media for 30 housewives who were members of the PKK Dasawisma 2 Lingkungan 6 Taas Subdistrict, Tikala District, Manado City. The variable measured is the level of knowledge using a questionnaire. The results of the activity show that based on the measurement of the level of knowledge about clean and healthy behavior in household into the good category. However, there are several indicators that still need to be improved, such as washing hands properly and doing physical activity every day for at least 30 minutes.
\end{abstract}

Keyword: knowledge; housewives; clean and healthy behavior

\section{PENDAHULUAN}

Saat ini dunia sedang mengalami krisis kesehatan dengan muncul dan menyebarnya novel coronavirus 2019 (2019-nCoV) atau dikenal dengan penyakit Corona Virus Disease 2019 (COVID-19). Virus ini berasal dari kelelawar dan ditularkan ke manusia melalui hewan vektor yang belum teridentifikasi di Wuhan, provinsi Hubei, China pada Desember 2019. Ada sekitar 45,5 juta kasus terkonfirmasi positif dan 1,19 juta kematian yang dilaporkan di seluruh dunia. Indonesia melaporkan sebanyak 410 ribu kasus positif dan 13.869 kasus kematian. Pada Provinsi Sulawesi Utara dilaporkan kasus positif sebanyak 5.388 kasus dengan 200 kasus 
meninggal. Kota Manado, ditemukan sebanyak 2201 kasus positif dengan 108 meninggal hingga saat ini (30/10/2020) (Singhal, 2020; Satgas Covid-19, 2020; Prov. Sulut, 2020; Pemkot Manado, 2020).

Penyakit ini ditularkan melalui penghirupan atau kontak dengan tetesan yang terinfeksi dan masa inkubasinya berkisar antara 2 hingga 14 hari. Gejalanya biasanya demam, batuk, sakit tenggorokan, sesak napas, kelelahan, malaise. Penyakit ini ringan pada kebanyakan orang; pada beberapa orang (biasanya orang tua dan orang dengan penyakit penyerta), dapat berkembang menjadi pneumonia, sindrom gangguan pernapasan akut dan disfungsi multi organ. Banyak orang tidak menunjukkan gejala. Tingkat kematian kasus diperkirakan berkisar antara 2 hingga $3 \%$ (Singhal, 2020).

Penelitian dari Sajed dan Amgain (2020), menyatakan bahwa mencuci tangan dengan benar, menggunakan masker, tinggal di rumah dan menjaga jarak terbukti sebagai tindakan pencegahan yang paling efektif dan merupakan solusi langsung untuk menyelamatkan manusia dari musuh yang tak terlihat ini $^{5}$. Selain itu, aktifitas fisik dan mengkonsumsi makanan bergizi merupakan salah satu cara mencegah terjadinya penyakit ini.

Mencuci tangan dengan benar, aktifitas fisik dan konsumsi makanan bergizi merupakan indikator pada perilaku hidup bersih dan sehat tatanan rumah tangga. Perilaku Hidup Bersih dan Sehat (PHBS) merupakan semua perilaku kesehatan yang dilakukan atas kesadaran, sehinga anggota keluarga atau keluarga dapat menolong dirinya di bidang kesehatan dan berperan aktif dalam kegiatan-kegiatan kesehatan masyarakat. PHBS merupakan langkah terbaik dalam pencegahan penyebaran virus ini, sehingga perlu ditanamkan kepada semua lapisan lapisan masyarakat tentang pengetahuan PHBS (Karo, 2020).

Merubah kebiasaan memanglah sulit, oleh karena itu, semua akan berubah dengan melakukan PHBS, dan merubah karakter setiap individu ke arah yang lebih baik dan nantinya membuat kualitas hidup manusia semakin baik. Pengalaman selama pandemi ini akan membuat mereka terbiasa melakukan perilaku hidup bersih dan sehat di kemudian hari (Karo, 2020).

Berdasarkan analisis pencapaian PHBS Tahun 2013 mencatat Proporsi Nasional rumah tangga dengan PHBS baik sebanyak 11.840.461 (55.46\%). Dengan proporsi rumah tangga yang ber-PHBS tertinggi di provinsi Kalimantan Timur sebesar $75.26 \%$ diikuti oleh Jawa Tengah sebesar $75.14 \%$. Sedangkan persentase terendah di Provinsi Papua Barat sebesar 25.50\% kemudian Nusa Tenggara Barat sebesar $28.94 \%$. Sebanyak 20 provinsi mempunyai prevalensi Rumah Tangga Ber-PHBS di bawah proporsi atau presentase nasional. Data di Sulawesi Utara menunjukkan sebanyak 70,7\% rumah tangga sudah melaksanakan PHBS (Rayhana dan Triana, 2017).

Pemberdayaan keluarga atau rumah tangga untuk melaksanakan PHBS tidak terlepas dari peran orangtua, terutama ibu. Dalam rumah tangga ibu mempunyai peran yang sangat besar dalam memberi contoh, teladan, pendidikan di suatu keluarga daripada ayah. Ibu juga lebih mendominasi dalam hal pengaturan menu makanan dan menjaga kebersihan rumah, termasuk didalam memberikan pendidikan kesehatan di keluarga (Depkes RI, 2009). Berdasarkan hal tersebut maka dilakukan kegiatan penyuluhan/ promosi kesehatan tentang PHBS tatanan rumah tangga pada ibu rumah tangga. Tujuan penulisan artikel ini yaitu untuk menggambarkan tingkat pengetahuan ibu rumah tangga tentang PHBS tatanan rumah tangga.

\section{METODE PELAKSANAAN}

Kegiatan ini dilakukan pada ibu-ibu pemberdayaan kesejahteraan keluarga (PKK) Dasawisma 2 Lingkungan 6 Kelurahan Taas Tikala Manado. Kegiatan ini dilakukan pada 26 Oktober 2020. Subyek penyuluhan sebanyak $30 \mathrm{ibu}$ yang hadir pada saat kegiatan dilaksanakan. Variabel yang diukur yaitu tingkat pendapatan, kepercayaan (masyarakat dalam melaksanakan PHBS), peran petugas kesehatan dan tingkat pengetahuan tentang PHBS tatanan rumah tangga. Metode penyuluhan dilakukan secara ceramah. Media penyuluhan menggunakan leaflet. Pengukuran 
tingkat pengetahuan dilakukan setelah dilakukan penyuluhan. Alat ukur pengetahuan menggunakan kuesioner. Kuesioner ini terdiri dari 10 pertanyaan tentang pengetahuan PHBS. Hasil analisis data ditampilkan secara deskripsi.

\section{HASIL DAN PEMBAHASAN}

Distribusi responden berdasarkan tingkat pendapatan, kepercayaan dan pelayanan kesehatan tentang PHBS dapat dilihat pada tabel 1 .

Tabel 1. Distribusi responden berdasarkan pendapatan, kepercayaan dan peran petugas kesehatan

\begin{tabular}{|c|c|c|c|}
\hline \multicolumn{2}{|c|}{ Kategori } & \multirow{2}{*}{$\frac{\mathrm{n}}{15}$} & \multirow{2}{*}{$\frac{\text { \% }}{50,0}$} \\
\hline Tingkat pendapatan & Rendah & & \\
\hline & Sedang & 9 & 30,0 \\
\hline & Tinggi & 6 & 20,0 \\
\hline & Total & 30 & 100,0 \\
\hline \multirow[t]{3}{*}{ Kepercayaan } & Kurang Baik & 9 & 30,0 \\
\hline & Baik & 21 & 70,0 \\
\hline & Total & 30 & 100,0 \\
\hline Peran petugas kesehatan & Baik & 30 & 100,0 \\
\hline
\end{tabular}

Data pada Tabel 1 menunjukkan bahwa responden terdistribusi paling banyak pada tingkat pendapatan rendah $(<1$ juta per bulan) sebanyak 50\%, kepercayaan yang baik (70\%) dan peran petugas kesehatan yang sudah baik (100\%). Selanjutnya berdasarkan hasil analisis diperoleh bahwa tingkat pengetahuan ibu rumah tangga berdasarkan pertanyaan yang diberikan menunjukkan bahwa nilai terendah 15 dan tertinggi 19 dimana nilai maksimal yang bisa diperoleh yaitu 20. Kategori tingkat pengetahuan dibagi menjadi 3 yaitu baik jika memperoleh nilai 1520, kurang baik jika memperoleh nilai 10-14 dan tidak baik jika memperoleh nilai < 10. Nilai rata-rata pengetahuan ibu-ibu diperoleh sebesar 17,53. Berdasarkan kategori tingkat pengetahuan, nilai-nilai ini sudah masuk kategori baik sehingga bisa dinyatakan bahwa pengetahuan ibu rumah tangga di Dasawisma 2 PKK Lingkungan 6 Kelurahan Taas Kecamatan Tikala Kota Manado masuk pada kategori baik.

Hasil penelitian dari Tontuli et al (2020) menunjukan bahwa tingkat pengetahuan ibu rumah tangga tentang perilaku hidup bersih dan sehat (PHBS) di atas $50 \%$ berpengetahuan baik. Rosidin dan Suhendar (2018) menyatakan bahwa adanya perubahan peningkatan pengetahuan dan pemahaman peserta mengenai PHBS yang diukur dengan hasil apersepsi dan review terjadinya peningkatan prosentase dari $74 \%$ yang awalnya belum mengetahui dan memahami menjadi hampir seluruhnya warga masyarakat yang hadir mengetahui dan memahaminya bahkan akan melaksanakan PHBS dengan tujuan agar rumah tangganya sendiri dalam keadaan sehat sesuai ketentuan yang tercantum dalam PHBS.

Sebanyak 10 pertanyaan yang diberikan ditemukan pertanyaan yang memperoleh skor rata-rata terendah yaitu pertanyaan nomor 5 (skor 1,03), nomor 7 dan 10 (masing-masing skor 1,57). Pertanyaan nomor 5 tentang kebiasaan mencuci tangan dengan benar, pertanyaan nomor 7 dan tentang aktifitas fisik dan sasaran PHBS. Ketiga hal ini masih perlu ditingkatkan pengetahuannya.

Karo (2020) menyatakan bahwa PHBS merupakan starategi yang dapat mencegah penyebaran Covid-19. Masyarakat terus dihimbau untuk meningkatkan prilaku hidup bersih dan sehat dalam upaya pencegahan penyebaran Covid-19, karena perilaku masyarakat sangat berperan penting dalam penurunan angka penyebaran Covid-19. PHBS merupakan salah satu starategi dalam pencegahan penyebaran Covid -19 yang sangat efektif dan mudah dilakukan oleh semua lapisan masyarakat. Rekomendasi pemerintah terus menghimbau gerakan PHBS menjadi kunci pencegahan penyebaran Covid-19 pada masa pandemik ini. Melakukan PHBS diharapkan penyebaran Covid-19 dapat dihambat sehingga kejadian tidak bertambah. Oleh karena pentingnya perilaku hidup bersih dan sehat, perlu dilakukan pemberian informasi secara terus menerus sehingga dapat meningkatkan pengetahuan seluruh lapisan masyarakat untuk menerapkan PHBS dalam kehidupan sehari-hari.

Menurut Medea et al (2019) adanya kegiatan penyuluhan tentang perilaku mencuci tangan dengan benar di SDN Inpres Salurang maka siswa menerapkan 
mencuci tangan dengan benar dengan menggunakan sarana yang tersedia yaitu wastafel. Salah satu alternatif dalam mencuci tangan yaitu penggunaan hand sanitizer. Hand sanitizer bisa menjadi bahan pengganti sabun dalam mencuci tangan. Selain itu bisa mengurangi penggunaan air dalam mencuci tangan. Salah satu hand sanitizer alami yaitu daun jeruk purut. Pramardika et al (2019), cara pembuatan hand sanitizer dari daun jeruk purut yaitu dimulai dengan daun jeruk purut dicuci bersih dengan air mengalir kemudian dikeringkan dan ditimbang sebanyak 40 gram. Setelah itu daun tersebut dipotong menjadi kecil-kecil agar minyak atsiri dapat keluar dengan mudah. Setelah itu, siapkan air sebanyak $100 \mathrm{cc}$ dan masukan potongan daun tersebut dan rebus hingga mendidih kemudian matikan api kompornya dan dinginkan pada suhu ruangan setelah itu saring rebusan itu dan masukan air hasil saringan tersebut ke dalam botol spray dan hand sanitizerpun siap untuk digunakan. Pada konsentrasi tersebut hand sanitizer alami sama efektifnya seperti hand sanitizer nonalami, yaitu dapat membunuh 46,10 CFU/ $\mathrm{cm}^{2}$ yang terdapat pada tangan seseorang (Widura, 2017).

Hand-sanitizer adalah produk pembersih tangan dalam bentuk gel yang mengandung zat antiseptik yang digunakan untuk mencuci tangan tanpa harus membilasnya dengan air. Penggunaannya lebih efektif membunuh flora residen dan flora transien daripada mencuci tangan dengan sabun antiseptik atau dengan sabun biasa dan air. Produk berbasis alkohol, yang mencakup hampir semua produk "disinfektan", mengandung larutan alkohol persentase tinggi (biasanya 60-80\% etanol) dan membunuh virus dengan cara yang sama. Sabun lebih baik karena hanya membutuhkan sedikit air sabun, yang, dengan menggosok, menutupi seluruh tangan dengan mudah. Dengan merendam virus dalam etanol untuk sesaat, dan menyeka atau menggosok gel di tangan tidak menjamin bahwa bisa merendam setiap sudut kulit di tangan dengan cukup efektif (Nakoe et al, 2020).

\section{KESIMPULAN}

Kesimpulan dari kegiatan ini yaitu tingkat pengetahuan ibu-ibu rumah tangga di Dasawisma 2 Lingkungan 6 Kelurahan Taas Kecamatan Tikala Kota Manado semuanya masuk pada kategori baik namun masih perlu peningkatan khusus pada perilaku mencuci tangan dan aktifitas fisik (berolahraga). Oleh karena itu dibutuhkan upaya penyuluhan secara berkala sehingga semua indikator PHBS tatanan rumah tangga bisa menjadi lebih baik.

\section{UCAPAN TERIMA KASIH}

Ucapan terima kasih disampaikan kepada Pimpinan Universitas Sam Ratulangi Manado melalui Lembaga Penelitian dan Pengabdian Masyarakat yang telah memberikan bantuan dana dalam pelaksanaan kegiatan ini.

\section{DAFTAR RUJUKAN}

Departemen Kesehatan RI. 2009. Rumah Tangga Berperilaku Hidup Bersih dan Sehat. Pusat Promosi Kesehatan. Jakarta

Hammami, A., Harrabi, B., Mohr, M., \& Krustrup, P. (2020). Physical activity and coronavirus disease 2019 (COVID-19): specific recommendations for home-based physical training. Managing Sport and Leisure, 1-6.

Karo, M. B. (2020). Perilaku Hidup Bersih dan Sehat (PHBS) Strategi Pencegahan Penyebaran Virus Covid-19. In Prosiding Seminar Nasional Hardiknas (Vol. 1, pp. 1-4).

Karo, M. B. (2020. Perilaku Hidup Bersih dan Sehat (PHBS) Strategi Pencegahan Penyebaran Virus Covid-19. In Prosiding Seminar Nasional Hardiknas (Vol. 1, pp. 1-4).

Medea, G. P., Hinonaung, J. S. H., \& Mahihody, A. J. (2019). Perilaku Mencuci Tangan dengan Benar di SDN Inpres Salurang Kecamatan Tabukan Selatan Tengah Kabupaten Kepulauan Sangihe. Jurnal Ilmiah Tatengkorang, 3, 35-38.

Nakoe, R., Lalu, N. A. S., \& Mohamad, Y. A. (2020). Perbedaan Efektivitas Hand-Sanitizer Dengan Cuci Tangan Menggunakan Sabun Sebagai Bentuk Pencegahan Covid19. Jambura Journal of Health Sciences and Research, 2(2), 65-70.

Pemerintah Kota Manado. 2020. Informasi dan Koordinasi Covid 19 (online) diakses dari https://covid19.manadokota.go.id/ pada 31 Oktober 2020 
Pramardika, D., Tooy, G. C., \& Umboh, M. J. (2019). Pelatihan Pembuatan Hand Sanitizer Alami di Kawasan Objek Wisata Pesisir Pantai Embuhanga Kabupaten Kepulauan Sangihe. Jurnal Ilmiah Tatengkorang, 3, 1418.

Provinsi Sulawesi Utara. 2020. Angka Kejadian Covid 19 di Sulawesi Utara (onlien) diakses dari https://corona.sulutprov.go.id/ pada 31 Oktober 2020

Rayhana, R., \& Triana, R. A. (2017). Hubungan Karakteristik, Pengetahuan dan Sikap terhadap Perilaku Hidup Bersih dan Sehat pada Ibu Rumah Tangga di Kelurahan Kebalen Kecamatan Babelan Bekasi Utara Tahun 2016. Jurnal Kedokteran dan Kesehatan, 12(2), 168-180.

Rosidin, U., \& Suhendar, I. (2018). Penyuluhan Perilaku Hidup Bersih dan Sehat (PHBS) Tatanan Rumah Tangga Di RW 14 Desa Jayaraga Tarogong Kidul Kabupaten Garut. Jurnal Kreativitas Pengabdian Kepada Masyarakat (PKM), 1(2).
Sajed, A. N., \& Amgain, K. (2020). Corona virus disease (COVID-19) outbreak and the strategy for prevention. Europasian Journal of Medical Sciences, 2(1), 1-3.

Satuan Tugas Penanganan Covid-19. 2020. Peta Sebaran (online) diakses dari https://covid19.go.id/peta-sebaran pada 31 Oktober 2020

Singhal, T. (2020). A review of coronavirus disease2019 (COVID-19). The Indian Journal of Pediatrics, 1-6.

Tontuli, E., Paturusi, A., \& Mokoagow, A. (2020). Tingkat Pengetahuan Ibu Rumah Tangga Tentang Perilaku Hidup Bersih dan Sehat (PHBS) di Desa Onkaw I Kecamatan Sinonsayang. Epidemia: Jurnal Kesehatan Masyarakat Unima, 12-17.

Widura, R. 2017. Efektifitas Air Rebusan Daun Jeruk Purut (Citrus Hystrik D.C) Sebagai Hand Sanitizer Alami Terhadap Penurunan Angka Kuman Telapak Tangan (unpublished). Skripsi. Politeknik Kesehatan Padang 